\title{
ANALYSIS OF ACTIVITIES AND PROSPECTS OF DEVELOPMENT OF TOURIST BUSINESS ENTITIES
}

\author{
Aleshchenko L. O.
}

\section{INTRODUCTION}

At the present stage, the tourism industry in the world has a significant impact on the functioning of the economic system of each country. Stable development of the tourism sector has a positive impact on socio-economic processes - new jobs are created, budget revenues increases, the welfare of the population also increases. According to the UN World Tourism Organization, the contribution of tourism to the world's gross domestic product is $10 \%$, and in Ukraine, this industry is just beginning to develop, not using the significant tourist and recreational potential of most regions. During the crisis caused by the coronavirus pandemic, the problems of domestic tourism development become relevant and the issue of financial support of the industry as a whole, including through investments, becomes quite acute.

One of the main components of an efficient economy around the world is entrepreneurship. It creates the conditions for effective economic development and growth, which leads to lower unemployment and creates conditions for increasing the number of jobs. The experience of the whole world shows that small and medium-sized businesses play a key role in ensuring employment and economic growth. Therefore, the rather difficult situation in the world and the difficult state of the economy in the country have increased the need for the formation of these forms of entrepreneurship. In turn, the tourism sector in the world economy is a very attractive type of financial activity that brings high and stable profits.

Realization of the set strategic tasks in the tourist branch of Ukraine is possible only on the basis of active introduction of small and medium business in the sphere of tourism, development of the organizational and economic mechanism of effective cooperation of subjects of tourism and authorities taking into account regional competitive advantages and available potential.

This study is devoted to the current state, problems, and prospects of development of tourism businesses in Ukraine in general and the Kherson region in particular. Proposals for the realization of the tourist potential of the southern region have been developed. On this basis, the task is to conduct an economic assessment of tourism businesses in the country and the region, identify types of tourism in which the region can be realized, and increase the 
attractiveness of domestic and foreign tourism; prospects for effective cooperation between the state and tourism businesses are grounded.

\section{Current state, problems and prospects of development of tourist business entities in Ukraine}

The Strategy for the Development of Tourism and Resorts for the period up to 2026 states that for the rational and efficient use of tourist, natural, medical and recreational resources of Ukraine it is necessary to form a tourist and recreational space by creating and ensuring the development of tourism and resorts and develop, implement and propose consumer competitive national tourism product. Therefore, tourism businesses face strategic goals to create a stable competitive advantage in the market by ensuring compliance with the price and quality of travel services and the implementation of standards that meet international level.

Successful development of tourism business in market conditions requires a constant increase in the level of competitiveness of each entity, providing a quality tourism product of growing demand, improving socio-economic relations of business structures, territorial associations and the state. The social mission of tourism is to increase the contribution to the cultural, economic and regional development of the country.

Conditions for creating an effective management system of investment processes in the tourism industry are to increase the scientific validity of management decisions in the field of investment, ensuring the interaction of such basic elements of the management system as principles, methods, management functions, tools to guide investment projects.

The economic activity of individual economic entities and tourism in the country as a whole is largely characterized by the volume and forms of investment processes. In a broad sense, investment is an input of capital in order to further increase it. In this case, the increase in capital should compensate the investor for refusing to use available funds for consumption in the current period, to reward him for the risk, to compensate for losses from inflation in the future ${ }^{1}$. Therefore, tourism will be attractive for investment on condition that its profitability increases.

The term "investment" comes from the Latin word "invest", which means "to invest". The Tax Code of Ukraine covers investments as business transactions that involve the acquisition of fixed assets, intangible assets, and corporate rights and/or securities in exchange for funds or property, i.e. the objects of investment are disclosed.

\footnotetext{
${ }^{1}$ Moroz, A.M. (2002). Bankivski operatsii [Banking operations]. 2 nd ed, KNEU, Kyiv, Ukraine.
} 
In the Law of Ukraine "On Investment Activity" the concept of "investment activity" is defined as a set of practical actions of citizens, legal entities and the state to implement investments, and investors are defined as investment entities that decide to invest their own, borrowed and attracted property and intellectual values in investing ${ }^{2}$.

Sharko M.V., Meshkova-Kravchenko N.V., Radkevych O.M. reveal the concept of "investment project" as a program of measures related to the implementation of investments, with a view to their subsequent reimbursement and profit, the define the investment process as deployed in time implementation of the investment project, where the beginning is the decision to invest, and the result is the achievement of the goal, or forced termination of the project ${ }^{3}$.

Based on the study of the theoretical nature of investment processes, it should be noted that investment in the tourism industry should be considered as the use of financial resources in the form of current and long-term investments to obtain the desired return both domestically and abroad.

Malskaya M.P. in her scientific works notes that investment in tourism is the placement of investor's capital in the tourism business to make a profit. Since capital is one of the main factors of production, the ability of the tourism industry to produce a quality tourism product (service) directly depends on the amount of capital invested ${ }^{4}$.

Objects and subjects of investment activity in the field of tourism have specifics, as the tourism industry is characterized by species diversity, features of development, resources used, organization of business processes.

The following objects of investment in the field of tourism can be distinguished: property of entrepreneurs in the field of tourism, tourist routes, historical objects, museums, libraries, green areas, technical products, places for accommodation of tourists, countryside.

The subjects for investment are: private investors, the state, foreign programs and grants, cooperatives, local governments, financial institutions, owners of the tourism business.

Investments play an important role in managing tourism development both in the country as a whole and in the regions. Volumes of investments should be analyzed and forecast in the process of developing measures for the formation of material and technical base of tourism, schemes of

${ }^{2}$ Zakon Ukrainy «Pro investytsiinu diialnist» (1991). [The Law of Ukraine “On Investment Activity”]. URL: https://zakon.rada.gov.ua/laws/show/1560-12\#Text

${ }^{3}$ Sharko, M.V. Mushkova-Kravchenko, N.V. and Radkevich, O.M. (2016). Ekonomika pidpryiemstva [Economy of the Enterprise]. Oldi-plus, Kherson, Ukraine.

${ }^{4}$ Malska, M.P. (2008). Mizhnarodnyi turyzm i sfera posluh [International tourism and the sphere of services]. Znannia, Kyiv, Ukraine. 
accommodation and development of tourist facilities, tax forecasting, formation of data banks of tourist investment projects, measures for standardization, certification of tourist products, licensing of certain activities, when planning employment and income, infrastructure development ${ }^{5}$.

Tourism should become one of the priority sectors in the economy of Ukraine. The state and regions develop and implement projects and programs in this area. For the effective functioning of the tourism industry it is necessary to include in the developed strategy of tourism development sections with investment proposals, to form an idea of a favorable tourist image of the country, to create favorable conditions for tourism development in order to attract investors.

Factors that encourage investment can be different:

- desire to increase sales and services in tourism;

- the need to update and improve the existing material and technical base (improvement of facilities, equipment, implementation of a modern reservation system);

- the desire to develop new activities (entering the market of the tourism industry with a new tourism product or a new type of service).

These factors emphasize the importance of investment in creating an economic base to address socio-economic problems. To increase the inflow of foreign investment into the economy, it is necessary to create a favorable investment climate. The investment climate is a set of social, economic, organizational, legal, political, socio-cultural prerequisites, which determines the attractiveness and feasibility of investing in the economy ${ }^{6}$.

Characterizing investment activities in Ukraine, it is necessary to emphasize the importance of investment in tourism. Tourism has a significant impact on the economy and development of the region, contributes to the inflow of currency into the country, creating new jobs, improving infrastructure. To get the most out of tourism, each state develops a tourism policy, which is one of the areas of socio-economic policy of the state.

The growth of income from tourism indicates an increase in its investment attractiveness. Table 1 highlights the revenues from the provision of tourist services for 2017-2019.

${ }^{5}$ Shuplat, O.M. (2016). Finansuvannia investytsiinoi diialnosti pidpryiemstv sfery turyzmu: teoretychnyi aspekt [Financing of investment activity of enterprises in the sphere of tourism: theoretical aspect]. Investytsii: praktyka ta dosvid, vol. 15, pp. 28-33.

${ }^{6}$ Tretyak, N. (2013). Faktory formuvannia investytsiinoho klimatu v Ukraini [Factor for the formulation of the investment class in Ukraine]. Finansovyi prostir, vol. 3, pp. 165-170. 
Revenues from the provision of tourist services

\begin{tabular}{|l|c|c|c|c|}
\hline \multirow{2}{*}{\multicolumn{1}{|c|}{ Indicators }} & \multicolumn{3}{c|}{ Years } & $\begin{array}{c}\mathbf{2 0 1 9} \\
\text { in \% to } \\
\mathbf{2 0 1 7}\end{array}$ \\
\cline { 2 - 5 } & $\mathbf{2 0 1 7}$ & $\mathbf{2 0 1 8}$ & $\mathbf{2 0 1 9}$ & \\
\hline Legal entities & & & \\
\hline $\begin{array}{l}\text { Income from the provision } \\
\text { of tourist services } \\
\text { (excluding VAT, excise tax } \\
\text { and similar mandatory } \\
\text { payments), thousand UAH }\end{array}$ & 18502975,3 & 21069268,5 & 31948701 & 172,7 \\
\hline \begin{tabular}{l|l|l|l|} 
including excursion activities \\
Individual entrepreneurs
\end{tabular} & 57565,5 & 89220,9 & 113651 & 197,4 \\
\hline $\begin{array}{l}\text { Income from the provision } \\
\text { of tourist services } \\
\text { (excluding VAT, excise tax } \\
\text { and similar mandatory } \\
\text { payments), thousand UAH }\end{array}$ & 519654,3 & 556652,4 & 751474,8 & 144,6 \\
\hline
\end{tabular}

Revenues from the provision of travel services for both legal entities and individuals are growing rapidly. If in 2017 the income of legal entities in the field of tourism services amounted to UAH 18,503 million, in 2019 it increases to UAH 31,949 million, or $72.7 \%$. Revenues from excursion activities also doubled. Individual entrepreneurs also provided an increase in income by $44.6 \%$ - from 519.6 to 751.5 million UAH.

Thus, the data of official statistics of Ukraine show that the income from the provision of services in the field of tourism is growing every year, while the tourism business is an industry that generates the development of related industries - hotel and restaurant business, small business in arts, sports, entertainment and recreation, contributes to rural development. Therefore, attracting investment in tourism, in our opinion, should be considered in terms of the relationship with these industries (Table 2).

Despite the positive dynamics in terms of growth of capital investments in Ukraine as a whole, in the activities of travel agencies, tour operators, the provision of other booking services, unfortunately, there is a decrease in investment. However, the tourist sphere should also include a set of hotels and other accommodation, restaurants, vehicles, recreation and entertainment facilities, catering facilities. Given the dynamics of investment in the above objects, it is possible to conclude that in most categories there is an increase in investment. 


\section{Structure and dynamics of used capital investments in the tourism sector, thousand UAH}

\begin{tabular}{|c|c|c|c|c|}
\hline \multirow[b]{2}{*}{ Indicators } & \multicolumn{3}{|c|}{ Years } & \multirow{2}{*}{$\begin{array}{c}2019 \\
\text { in \% } \\
\text { to } \\
2017\end{array}$} \\
\hline & 2017 & 2018 & 2019 & \\
\hline $\begin{array}{l}\text { Capital investments } \\
\text { (total in Ukraine) }\end{array}$ & 448461518 & 578726385 & 623978935 & 139,1 \\
\hline $\begin{array}{l}\text { 1. Activities of travel agencies, tour } \\
\text { operators, other booking services } \\
\text { and related activities }\end{array}$ & 104087 & 236640 & 79566 & 76,4 \\
\hline $\begin{array}{l}\text { 2. Temporary accommodation and } \\
\text { catering (total), including: }\end{array}$ & 2133519 & 2675101 & 2832178 & 132,7 \\
\hline - $\quad$ temporary accommodation & 1380054 & 1473043 & 982887 & 71,2 \\
\hline $\begin{array}{l}\text { activities of hotels and simi- } \\
\text { lar temporary accommodation }\end{array}$ & 1231268 & 1231042 & 837322 & 68,0 \\
\hline $\begin{array}{l}\text { activity of accommodation } \\
\text { facilities for the period of vacation } \\
\text { and other temporary residence }\end{array}$ & 131053 & 223910 & 117700 & 89,8 \\
\hline - $\quad$ food and beverage activities & 753465 & 1202058 & 1849291 & 245,4 \\
\hline $\begin{array}{l}\text { activities of restaurants, } \\
\text { provision of mobile food services }\end{array}$ & 664385 & 1091217 & 1710057 & 257,4 \\
\hline$-\quad$ delivery of ready meals & 77213 & 80226 & 40736 & 52,7 \\
\hline - $\quad$ beverage service & 11867 & 30615 & 98498 & 830,0 \\
\hline $\begin{array}{l}\text { 3. Art, sports, entertainment and } \\
\text { recreation (total), including }\end{array}$ & 1649225 & 3663168 & 4146160 & 251,4 \\
\hline $\begin{array}{l}\text { functioning of libraries, } \\
\text { archives, museums and other } \\
\text { cultural institutions }\end{array}$ & 321736 & 601399 & 605129 & 188,0 \\
\hline $\begin{array}{l}\text { 4. Activities in the field of sports, } \\
\text { recreation and entertainment (total), } \\
\text { including: }\end{array}$ & 1062982 & 2636470 & 3065792 & 288,4 \\
\hline - $\quad$ activities in the field of sports & 563434 & 1820718 & 1658461 & 294,3 \\
\hline $\begin{array}{l}\text { - organization of recreation and } \\
\text { entertainment }\end{array}$ & 499548 & 815752 & 1407331 & 281,7 \\
\hline $\begin{array}{l}\text { 5. Provision of other types of } \\
\text { services }\end{array}$ & 637612 & 571579 & 672504 & 105,4 \\
\hline
\end{tabular}


Ukraine has significant potential in the development of tourism, but a low level of image in the global investment market. In most rankings, the country ranks last in terms of investment attractiveness. Therefore, an important task of increasing investment in the tourism business is to increase investment attractiveness.

Investment attractiveness of tourism is a set of micro and macro factors that form the general idea of a potential investor about the state and level of development of the tourism industry in the country and give him the opportunity to determine how attractive and profitable the country can be to invest in this area. In Ukraine, the tax and administrative burden on business, high inflation, the unstable political situation, and hostilities in eastern Ukraine significantly hinder the improvement of the investment attractiveness of the regions.

The investment attractiveness of the territories acts as a determining factor in choosing the object of investment. Indeed, given the resource needs of some market participants and the availability and desire to invest temporarily free funds in others, when concluding an agreement, investment attractiveness should be considered as a key category. Based on the statements of scientists about the essence of the investment potential of the region, it is possible to conclude that the formation involves the following components: natural resource potential, geographical location, economic status, infrastructure, institutional formations, staffing, scientific and technical potential, consumer component, production component.

The use of investment resources should be based on a reasonable choice of investment project. To ensure the right choice of solutions, organizations involved in tourism activities need to independently or with the help of experts to develop an effective sample of a new model, transform obsolete one and introduce new facilities. Modernization is crucial to increase economic efficiency through more efficient use of production factors, along with the introduction of new technologies and innovations. The economic result from the implementation of investment activities is estimated by increasing the income of business structures, optimizing costs and reducing the cost of services, increasing profits, which ultimately increases its competitiveness.

There are two main problems in assessing the investment component of tourism development:

1. Lack of a single information base for the implementation of investment projects. That is, it is the inadequate provision of data that allows an objective assessment of the investment security of the tourism industry, including statistics. There is also a single information base that would allow a potential investor to get acquainted with the materials needed for investment projects: area plan, business plan, master plan for tourist facilities that require investment, information on resource capacity. 
The solution to this problem can be the creation of a single site and register that will reflect current official data of the tourism industry, public discussions and projects of proposals from investors and stakeholders to improve the development of tourism in Ukraine.

2. Insufficiently favorable investment climate. That is, the existing requirements for starting and developing a tourism business sometimes do not allow investors to start construction of facilities for several years - this period of time is spent on the coordination of various decisions and paperwork. The way to eliminate this problem may be the adoption of regulations that help attract investment in economic development, the introduction of tax benefits, reducing the time to agree on decisions, the development of infrastructure networks.

Insufficient level of information support significantly reduces the interest of potential investors to join the financial support of tourism. Information that is freely available (the number and cost of tours sold by tour operators and travel agents, inbound and outbound flows, etc.) does not reflect all aspects of tourism development and is not able to interest potential investors.

Ukraine has created a legal framework in the field of investment regulation to achieve a greater inflow of investment and increase the efficiency of their use. However, the need to harmonize documents and permits in various government agencies creates temporary and other barriers to the implementation of investor plans.

Despite the high tourist and recreational potential in Ukraine, the development of tourism is quite slow. Investments in tourism are carried out mainly in regions where tourism is identified as one of the priority areas of economic development - the western region and the south. For the implementation of investment projects in the field of tourism it is necessary to conduct an economic justification for attracting investment funds, to provide solutions with clear calculations of profitability, payback period of the project, to develop a business plan for its implementation.

Thus, the formation of a favorable investment climate in Ukraine should be facilitated by large-scale comprehensive measures to improve the working conditions of investors, expand the mechanisms and tools for investment and implementation of investment projects. Increasing investment in Ukraine's economy will accelerate the socio-economic development of regions and priority industries.

\section{Prospects of development of tourist business of Kherson region}

The formation of competitive advantages of tourism entities is constantly in the focus of scientific and practical research. The problem of realization of the effective mechanism of formation of competitive advantages and, as a 
result, increase of competitiveness of domestic subjects of tourist business acquires special urgency in the period of European integration of economy of Ukraine and expansion of competition in the domestic market of tourist services.

The competitiveness of the region largely depends on a number of factors, namely the level of development of material production, nonproductive sphere and, in particular, from such an important sociohumanitarian industry as recreation and tourism. Therefore, to change the situation for the better it is necessary to improve the mechanisms of economic regulation taking into account the experience of countries with developed tourism, the formation of new socio-economic approaches to the strategy of national tourism and tourism management system at both state and regional levels.

Significant attention to the development of tourism in the Kherson region is paid by such domestic scientists as Yu. Kirilov, V. Granovska, G. Zhosan, I. Dotsenko ${ }^{78}$. However, many issues remain unexplored in full.

The Strategy for the Development of Tourism and Resorts for the period up to 2026 states that for the rational and efficient use of tourist, natural, medical and recreational resources of Ukraine it is necessary to form a tourist and recreational space by creating and ensuring the development of tourism and resorts and develop, implement and propose competitive national tourist product.

In the Development Strategy of Kherson region for the period 2021-2027 in the field of tourism in the implementation of the strategic goal "Local economic development taking into account digitalization and innovation and investment processes" as an operational goal is "Tourism and recreation industry for health, recreation and intellectual and spiritual enrichment". The development of recreational opportunities in the Kherson region is expected to develop harmoniously - both the Azov and Black Sea coastal regions. Also, due to the development of green tourism, the provision of services in the Lower Dnieper National Park will be expanded. The development of the tourism sector will take into account the maximum allowable level of anthropogenic pressure on the territory. The development

${ }^{7}$ Kyrylov, Y. Hranovska, V. Zhosan, H. and Dotsenko, I. (2020). "Innovative Development of Agrarian Enterprises of Ukraine in the Context of the Fourth Industrial Revolution", Solid State Technology, vol. 63, issue 6, pp. 1430-1448.

${ }^{8}$ Kyrylov, Y.Ye. Hranovska, V.G. and Alieshchenko, L.O. (2020). Ekonomichnyi mekhanizm formuvannia konkurentnykh perevah subiektiv turystychnoi haluzi [The economic mechanism of the formulation of competitive transfers of tourist services]. International scientific and practical magazine "Economics of the agro-industrial complex", vol. 5 , pp. 45. 
of tourism will be based on the use of cultural and recreational potential of the region ${ }^{9}$.

The goal will be achieved by extending the tourist season in recreational areas, improving the quality of tourist services through the introduction of certification of services based on international standards, development of new tourist complexes, creating conditions for the promotion of tourist products.

An important component will be the accessibility of tourist facilities through the introduction of a multilingual system of marking and navigation in the Kherson region, marking routes of active tourism, arranging landmarks of history and culture of the Steppe Black Sea coast, providing them with infrastructure for tourists.

Expected results:

- there will be a network of information support for the tourism industry;

- a system of standardization of accommodation establishments will be introduced;

- it is planned to mark tourist routes;

- extension of the tourist season from May to October;

- a training base should be created for the development of the tourism industry, namely the younger generation, which will be able to bring it to a new level.

The advantages of the Kherson region for the development of tourism businesses include:

1. Natural and climatic:

- unique climatic conditions that are attractive for tourists from the northern and western regions;

- the considerable duration of the frost-free period allows to attract more tourists during the year;

- the opportunity to develop gastronomic types of tourism on the basis of unique products that are produced only in the region;

- wide access to the Dnieper waterway;

- access to 2 seas at the same time - the Black sea and Azov sea;

- the only natural desert in Europe - Oleshkiv sands;

- the world's largest man-made forest;

- unique mountain landscapes in the middle of the steppe "Stanislavsky steppe".

${ }^{9}$ Pro skhvalennia Stratehii rozvytku turyzmu ta kurortiv na period do 2026 roku. Rozporiadzhennia Kabinetu ministriv Ukrainy (2017). [Order of the Cabinet of Ministries of Ukraine No. 168 "About the strategy for the development of tourism and health resorts for the period until 2026]. URL: https://zakon.rada.gov.ua/laws/show/168-2017-\%D1\%80 
2. Resort and recreational:

- 12 resort settlements;

- more than $450 \mathrm{~km}$ of sea coastline, of which $200 \mathrm{~km}$ are equipped with sandy beaches;

- the longest sand spit in the world - Arabat Split;

- more than 70 deposits of healing balneological resources (mineral and thermal waters, therapeutic muds, brines of salt lakes), including the unique Lemurian Lake, the therapeutic mud of which has undergone clinical trials, certified and approved for use as a therapeutic and cosmetic product;

- the city of Skadovsk, which is a resort of national importance, a center for children's health and recreation;

- more than 1000 objects of rest, improvement and accommodation, from them 49 children's, 60 estates of green tourism, 51 hotel complex;

- total bed capacity of more than 100 thousand seats.

3. Nature reserve fund of national, international and local significance:

- UNESCO-protected Black Sea and Askania-Nova Biosphere Reserves;

- National Nature Parks: "Azov-Sivasky", "Oleshkiv Sands", "Dzharilgatsky", "Lower Dnieper" and the recently established "Kamyanska Sich" ${ }^{10}$.

More than 90 tourist routes have been developed for the services of tourists in the territory of Kherson region of different directions and for different age categories, the most popular of which are: scientific and educational routes in the Askania-Nova Biosphere Reserve, walking routes in one of the largest sandy deserts in Europe "Oleshkiv Sands", visiting the shrine of the Ukrainian Cossacks, a monument of history of national importance Kamyanska Sich, objects of historical and cultural heritage of the regional center and other historical places.

Also water tourism, rural green, wine, environmental, historical and cultural, gastronomic tourisms are actively developing in the region.

Tourist offers meet the demand for atmospheric tours for every taste and for any age group, and at any time of year. These include kiting and yachting, kayaking, quad biking, fishing, hunting, open-air theater, visiting the "Tulip Valley", traveling the Cossack trails and many other tourist attractions.

Tourism, recreation, treatment and rehabilitation are becoming increasingly important in the socio-economic development of Kherson region. However, a significant part of natural areas, cultural heritage sites and tourist

${ }^{10}$ Stratehiia rozvytku Khersonskoi oblasti na period 2021-2027 rokiv [Strategy for the development of the Kherson region for the period 2021-2027 years], URL: https://khoda.gov.ua/strateg\%D1\%96ja-rozvitku-2021-2027 
infrastructure are not adapted to international requirements for tourist visits, and tourist services in all sectors of the tourism industry mostly do not meet the requirements for quality of service ${ }^{11}$.

Provision of tourist services in the region is provided by 14 tour operators, more than 100 travel agents and about 60 guides who serve visitors to museums, reserves, cultural and historical complexes. The analysis showed that this is more than not enough for the active development of tourism, so this area can become a priority for the development of youth entrepreneurship.

Therefore, for the active and successful development of tourism business and youth entrepreneurship, we consider it necessary to introduce the following measures:

1. Create conditions for the promotion of tourist products:

- brand formation and promotion, marketing policy;

- promotion of Kherson tourist region;

- creation of a network of regional tourist information center;

- development of the tourist brand of the Kherson region.

2. Improve the quality of the tourist services:

- improving the quality of training in the field of hospitality;

- promoting the implementation of state and international standards in the tourism sector;

- promoting the development and implementation of a multilingual system of marking and navigation in the Kherson region;

- assistance in marking routes of active tourism;

- arranging of landmarks of history and culture of the Steppe Black Sea coast, providing them with infrastructure for tourists.

3. Extend the tourist season:

- extension of the holiday season;

- support for rural green tourism;

- providing organizational, informational and promotional support for existing festivals and events that do not take place in the summer.

4. Create conditions for the development of domestic tourism:

- infrastructural provision of recreational territories of the region;

- ecological trails of Kherson region;

- formation and promotion of cases of tourist proposals (magnets) focused on domestic tourists (Clusters "Salt Road", "Tavria Ecological Health", Projects “Tavria SPA Resort”);

- development of enogastronomic tourism.

${ }^{11}$ Vidpochynok i turyzm u Khersonskii oblasti u 2019 rotsi: statystychnyi biulleten [Recreation and tourism in the Kherson region in 2019: statistical bulletin]. Holovne upravlinnia statystyky u Khersonskii oblasti, 2020. 54 s. 
5. Support for craft industries:

- implementation of projects for the production of craft products (cheese, dried fruits and vegetables, marinades, jams, wine, fruit and vegetable snacks, tobacco, spices, oysters, snails, crickets, etc.);

- health food based on oilseeds;

- creation of an agrotourism map of the region;

- creating incentives for growing environmentally friendly products and abandoning GMOs;

- introduction of organic farming.

6. Promote the development of entrepreneurship, including in rural areas:

- financial support for youth businesses by compensating for interest rates on loans;

- popularization of socially responsible business (implementation of measures to increase the level of tax discipline; introduction of effective innovative tools for communication with business, which will increase the level of respect for it).

The analysis of preconditions and tendencies of development of subjects of tourist business of the Kherson area allows to state that the area has considerable opportunities to enter the most developed regions of Europe in the tourist relation: favorable geopolitical location, comfortable microclimatic conditions, various landscape, unique flora and fauna, historical cultural, architectural heritage, developed transport network, sufficient human, material, including natural health resources.

At the same time, the tourism and resort industry needs active support from the state, attracting significant investments in the development of tourist and recreational infrastructure of the region and bringing it in line with international standards, increasing attention to the development of domestic inbound tourism.

\section{CONCLUSIONS}

Based on the research, it is determined that in the tourism industry there are processes of competition development based on the activities of tourism entities. The development of innovative priority types of tourism at the regional level is an important condition for their competitiveness in the market of tourist services. Qualitative factors of competitive advantages include natural-climatic, ecological, economic component, socio-cultural, image component. We believe that the unique characteristics of each region can be part of the implementation of the strategy of effective tourism development at the level of price and quality factors.

The analysis of preconditions and tendencies of development of subjects of tourist business of the Kherson area allows to state that the area has considerable opportunities to enter the most developed regions of Europe in 
terms of tourism: favorable geopolitical location, comfortable microclimatic conditions, various landscape, unique flora and fauna, historical, cultural, architectural heritage, developed network of transport links, sufficient human, material, including natural health resources.

At the same time, the tourism and resort industry needs active support from the state, attracting significant investments in the development of tourist and recreational infrastructure of the region and bringing it in line with international standards, increasing attention to the development of domestic inbound tourism.

\section{SUMMARY}

The purpose of the study is to determine the priorities for the development of tourism business in Ukraine in general and in the Kherson region in particular, and its role in realizing the tourism potential of the country.

The abstract-logical method (substantiation of theoretical positions, systematization of development factors), statistical analysis (characteristics of the state of the analyzed business sector) is used.

The potential of tourism entrepreneurship is a dynamic and creative response to the challenges of the external environment, the implementation of socially responsible business ideas, the propensity to innovate. Its activation in the tourism business involves creating conditions for the promotion, diversification and improvement of the quality of tourism products, stimulation of craft industries, state financial, legal and information support.

\section{REFERENCES}

1. Moroz, A.M. (2002). Bankivski operatsii [Banking operations]. 2 nd ed, KNEU, Kyiv, Ukraine.

2. Zakon Ukrainy "Pro investytsiinu diialnist" (1991). [The Law of Ukraine "On Investment Activity"], URL: https://zakon.rada.gov.ua/laws/ show/1560-12\#Text

3. Sharko, M.V. Mushkova-Kravchenko, N.V. and Radkevich, O.M. (2016). Ekonomika pidpryiemstva [Economy of the Enterprise]. Oldi-plus, Kherson, Ukraine.

4. Malska, M.P. (2008). Mizhnarodnyi turyzm i sfera posluh [International tourism and the sphere of services]. Znannia, Kyiv, Ukraine.

5. Shuplat, O.M. (2016). Finansuvannia investytsiinoi diialnosti pidpryiemstv sfery turyzmu: teoretychnyi aspekt [Financing of investment activity of enterprises in the sphere of tourism: theoretical aspect]. Investytsii: praktyka ta dosvid, vol. 15, pp. 28-33.

6. Tretyak, N. (2013). Faktory formuvannia investytsiinoho klimatu v Ukraini [Factor for the formulation of the investment class in Ukraine]. Finansovyi prostir, vol. 3, pp. 165-170. 
7. Kyrylov, Y. Hranovska, V. Zhosan, H. and Dotsenko, I. (2020). "Innovative Development of Agrarian Enterprises of Ukraine in the Context of the Fourth Industrial Revolution", Solid State Technology, vol. 63, issue 6, pp. 1430-1448.

8. Kyrylov, Y.Ye. Hranovska, V.G. and Alieshchenko, L.O. (2020). Ekonomichnyi mekhanizm formuvannia konkurentnykh perevah subiektiv turystychnoi haluzi [The economic mechanism of the formulation of competitive transfers of tourist services]. International scientific and practical magazine "Economics of the agro-industrial complex", vol. 5, pp. 45.

9. Pro skhvalennia Stratehii rozvytku turyzmu ta kurortiv na period do 2026 roku. Rozporiadzhennia Kabinetu ministriv Ukrainy (2017). [Order of the Cabinet of Ministries of Ukraine No. 168 "About the strategy for the development of tourism and health resorts for the period until 2026]. URL: https://zakon.rada.gov.ua/laws/show/168-2017-\%D1\%80

10. Stratehiia rozvytku Khersonskoi oblasti na period 2021-2027 rokiv [Strategy for the development of the Kherson region for the period 2021-2027 years]. URL: https://khoda.gov.ua/strateg\%D1\%96ja-rozvitku-2021-2027

11. Vidpochynok i turyzm u Khersonskii oblasti u 2019 rotsi: statystychnyi biulleten [Recreation and tourism in the Kherson region in 2019: statistical bulletin]. Holovne upravlinnia statystyky u Khersonskii oblasti, $2020.54 \mathrm{~s}$.

\section{Information about the author: Aleschenko Liudmyla Oleksandrivna,} Assistant at the Department of Management and Information Technologies Kherson State Agrarian and Economic University

23, Stritenska str., Kherson, Ukraine, 73006 orcid.org/0000-0002-7119-2922 